\title{
Diversity in Phenotypic Traits and Mineral Elements of Okra (Abelmoschus esculentus L. Moench) Genotypes
}

\author{
Ronke Justina Komolafe ${ }^{(D)},{ }^{1}$ Omolayo Johnson Ariyo $\left(\mathbb{D},{ }^{2}\right.$ \\ and Christopher Olusanya Alake $\mathbb{B D}^{2}$ \\ ${ }^{1}$ Department of Plant Science and Biotechnology, Federal University, Oye Ekiti, Ekiti State, Nigeria \\ ${ }^{2}$ Department of Plant Breeding and Seed Technology, Federal University of Agriculture, Abeokuta, Ogun State, Nigeria
}

Correspondence should be addressed to Ronke Justina Komolafe; ronke.komolafe@fuoye.edu.ng

Received 5 January 2021; Revised 10 March 2021; Accepted 15 March 2021; Published 24 March 2021

Academic Editor: Cristina Patan

Copyright (C) 2021 Ronke Justina Komolafe et al. This is an open access article distributed under the Creative Commons Attribution License, which permits unrestricted use, distribution, and reproduction in any medium, provided the original work is properly cited.

\begin{abstract}
African indigenous vegetables need to be improved for yield and nutrient enhancement. This can initially be done through germplasm characterization to know the pattern of genetic diversity for germplasm collection, conservation, and plant breeding programme. This research work was carried out to elucidate the diversity present in forty genotypes of okra in Nigeria as regards their qualitative and quantitative traits together with their mineral elements using cluster analysis and principal component analysis so as to help breeders in crop improvement programmes to select appropriate parents to produce new and better varieties. The experiment was carried out at the Teaching and Research Farm of the Department of Crop, Soil and Pest Management, Federal University of Technology, Akure, during the rainy season in 2019. Principal component analysis and cluster analysis were employed to study the diversity present in the okra genotypes. There was great diversity among the forty genotypes of okra studied with respect to qualitative traits. There were highly significant differences $(P<0.01)$ for all the quantitative characters, which indicated the presence of a great amount of diversity in all the characters studied. Single-linkage cluster analysis shows that, at $100 \%$ level of similarity, all the genotypes were distinct from one another. Results of the principal component analysis showed that $76.30 \%$ of the total variability among the okra genotypes evaluated in this study was accounted for the first five principal components. This study suggests that there is great diversity among the genotypes studied, which could be used by breeders for okra improvement.
\end{abstract}

\section{Introduction}

The growing population of the world today brought about by an increase in mortality rate necessitates the importance of improved farming systems and adequate crop improvement programmes. African indigenous vegetables need to be improved for yield and nutrient enhancement. Okra is one of the most important vegetable sources for viscous fibre, an important dietary component to lower cholesterol [1]. Most of the okra genotypes in Nigeria are adapted to particular ecological zones and climate and are mostly low yielding with a high rate of pest and disease infestation on the field. They are also local landraces with long maturity duration, nonuniform structure, and colour which make them unattractive for consumption and market utilization. Most of the Nigerian okra genotypes have varied nutritional compositions such as ascorbic acid and calcium [2] and protein and fat [3], which are essential to health in humans [4]. Most of the nutrients in okra comprise soluble fibre in the form of gums and pectins which help to lower serum cholesterol, reducing the risk of heart diseases [5]. Habtamu et al. [6] stated that potassium, sodium, magnesium, and calcium are the principal elements in pods of okra. Moyin-Jesu [7] also reported the presence of iron, zinc, manganese, and nickel in okra. Calcium is required for vascular contraction and vasodilation, muscle function, nerve transmission, intracellular signalling, and hormonal secretion [8]. The various research questions of this work include the following: Do all okra genotypes have the same fibre and elemental components? Do they have the same performance in terms of 
growth habit, flowering, and yield? Are there differences in the qualitative characters of the various genotypes? This problem can be solved through germplasm characterization to know the pattern of genetic diversity for germplasm collection, conservation, and plant breeding programme. This will helps breeders in crop improvement programmes in selecting appropriate parents to produce new and better varieties.

Kiran and Ravisankar [9] and Ariyo [10] reported that crop development through breeding is dependent on the availability of genetic variability present in germplasm and how variability could be set in genotypes without difficulty. Ren et al. [11] stated that the diversity present in accessions of okra will determine not only the number of accessions it contains but the value of the germplasm. Aladele et al. [12] also reported that the understanding of genetic variability and associations among okra germplasm may play an important role in breeding programmes to biotic and abiotic stresses of okra. Ariyo [13] reported that there was a significantly large variation among 30 within species of African genotypes of okra based on phenotypic assessment. Diversity derived from phenotypic and morphological traits generally varies with environments, and assessment of character is based on growing the plants to full maturity before identification [12]. Ariyo and Odulaja [14] reported that variability is more pronounced in the number of days to flowering, plant height at maturity, and various fruit characters among okra germplasm, which could be significant to differentiate varieties of $A$. esculentus. Knowledge of the genetic variability among directly related genotypes is crucial for reasonable use of plant genetic resources [15].

Principal component analysis (PCA) is a technique that can be used to condense large variables to a minute set that still retains most of the information of the large variable. It is a method used to accentuate variation in the germplasm of crops and reveal samples in a dataset. Through the use of it, experimental data can be easy to investigate and envisage. Cluster analysis is a statistical method used to group similar signatures or characteristics from observed values of many variables into a number of clusters.

Eshiet and Brisibe [16] reported that the development of new cultivars is dependent upon the availability of variations for morphological traits and yield-attributing characters which are genetically based. Kyriakopoulou et al. [17] stated that genetic diversity in okra has been measured using both morphological and agronomic traits. Many researchers have worked on the morphological characterization of okra using different methods with different varieties of okra and they have been able to exploit variability present in those germplasm [16-20], but none of them has taken into consideration the variation in their mineral elements which is an important factor to consider in the characterization of germplasm because the nutritive value of germplasm shows its quality. In addition, varieties of okra other than the ones used in the previous studies were incorporated into this study so as to exploit, assemble, and produce more and better germplasm for genebank conservation and for breeding work. This study was carried out to determine the diversity present in forty genotypes of okra in Nigeria as regards their qualitative and quantitative traits together with their mineral elements using cluster analysis and principal component analysis.

\section{Material and Methods}

The experiment was carried out at the Teaching and Research Farm of the Department of Crop, Soil and Pest Management, Federal University of Technology, Akure, Ondo State, Nigeria, during the rainy season between May and October 2019. Forty genotypes of okra were collected from the genebank of the National Centre for Genetic Resources and Biotechnology (NACGRAB), Ibadan, Oyo State, Nigeria. A total land area of $140 \mathrm{~m} \times 3.9 \mathrm{~m}$ was acquired and cleared, ploughed to a fine texture for planting. The experiment was laid out in a single-row plot in three replications in a randomised complete block design. Each row was $3 \mathrm{~m}$ long with a row-row distance of $0.5 \mathrm{~m}$. The plant was spaced $30 \mathrm{~cm}$ within rows to give 10 plants per row, i.e., $300 \mathrm{~cm}$ by $100 \mathrm{~cm}$ planting distance. Seeds of various genotypes were sown at a depth of $1 \mathrm{~cm}$ with three to four seeds per hole and later thinned to two per hill after germination. Weeding was carried out manually three weeks after planting and when necessary to keep the field weed free.

2.1. Data Analysis. Mean values of data collected were used for analysis of variance according to the procedures outlined by Gomez and Gomez [21] and separated by Duncan's multiple range test (DMRT). Percentage contribution of each trait to total genetic variability among the genotypes was determined by using principal component analysis while single-linkage cluster analysis was done to obtain a dendrogram to show the genetic relationships among the genotypes based on evaluation of the fourteen characters.

\section{Results}

3.1. Variation in Qualitative Characteristics of Forty Genotypes of Okra. There is great variation among the forty genotypes of okra fruits studied with respect to qualitative traits exhibited by the forty genotypes as shown in Figure 1. Okra plant at vegetative, flowering, and fruiting stages is presented in Figures 2-4.

From the results, okra genotypes showed a diverse level of differences in stem and fruit pubescence (Figure 5), which varies from prickly, downy, glabrous to slightly rough but with the majority being downy, followed by slightly rough, then prickly with glabrous being the least (Table 1). The stem colour ranges from green to purple, red-green to yellowishgreen, with the green stem being the most prominent. The petal colour was yellow in all the forty genotypes of okra studied. Fruit colour ranged from green to purple-green to yellowish-green, but okra fruits with green colour were most prominent. The positions of the fruits on the main stem were mostly erect while some were horizontal and few were pendulous. 

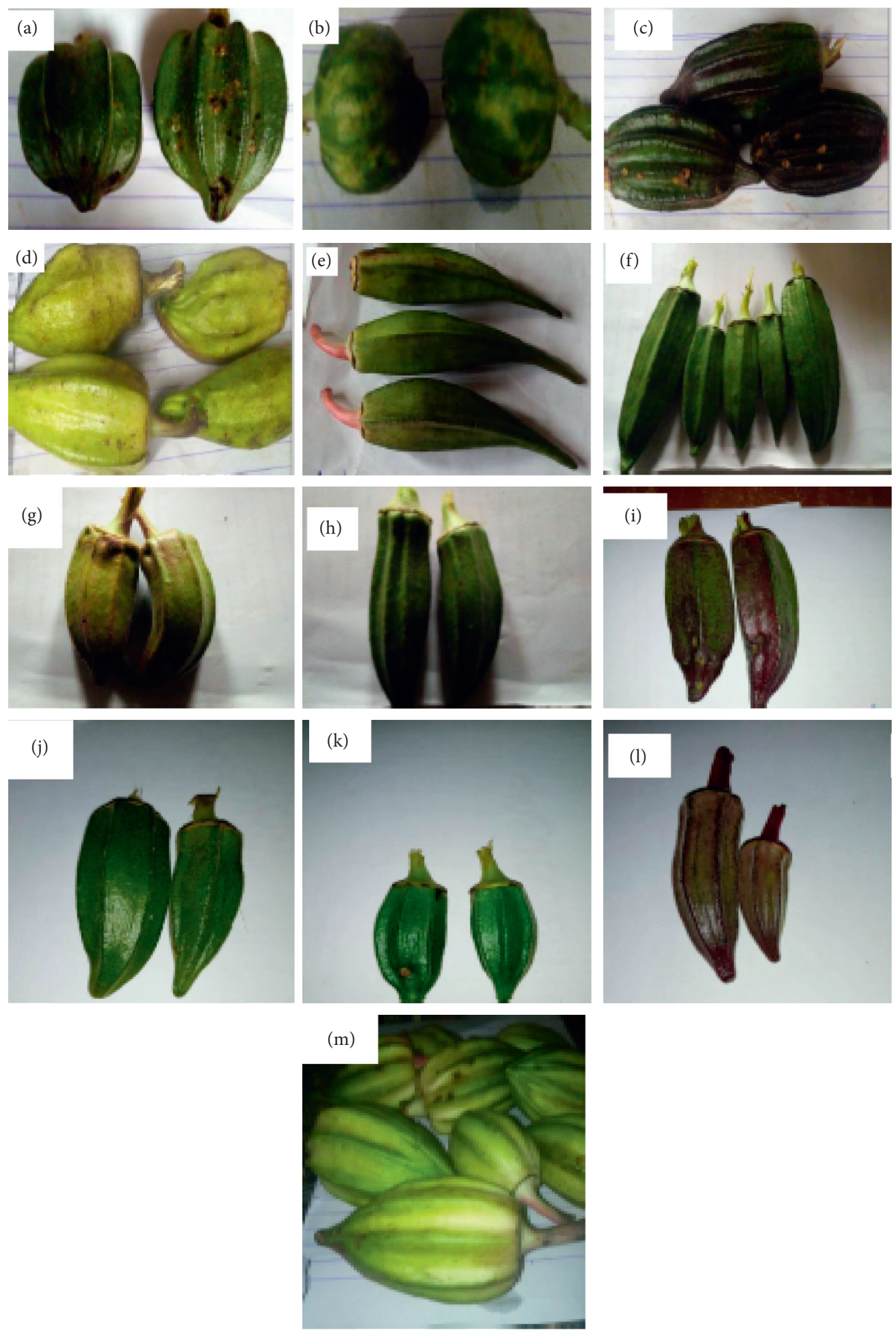

Figure 1: Variability in okra fruits: (a) NGB00386; (b) NGB00371; (c) NGB00486; (d) NGB00345; (e) NGB00470; (f) NGB00378A; (g) NGB00331; (h) NGB00356; (i) NGB00430; (j) NGB00299; (k) NGB00355; (l) NGB00304; (m) NGB00308.

3.2. Analysis of Variance and Mean Performance of Forty Genotypes of Okra. The analysis of variance for different traits is presented in Table 2. The mean sum of squares due to replications was nonsignificant for all the characters except for days to maturity which is significantly different from the entire trait evaluated. The variation due to treatments was highly significant for all the characters. Highly significant differences for all the characters indicated the presence of a great amount of variability in all the characters studied.

The highest plant height was recorded in NGB00308 (171.80) while the lowest plant height was recorded in NGB00297b (42.33) (Table 3). Accessions NGB00296A, 


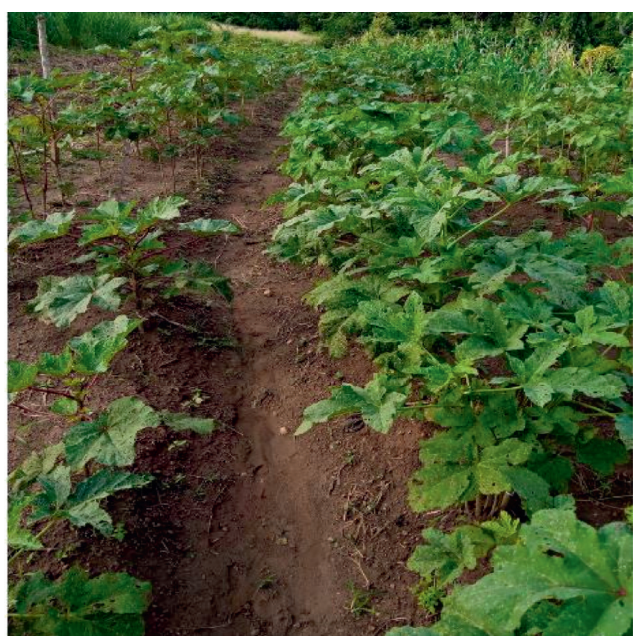

(a)

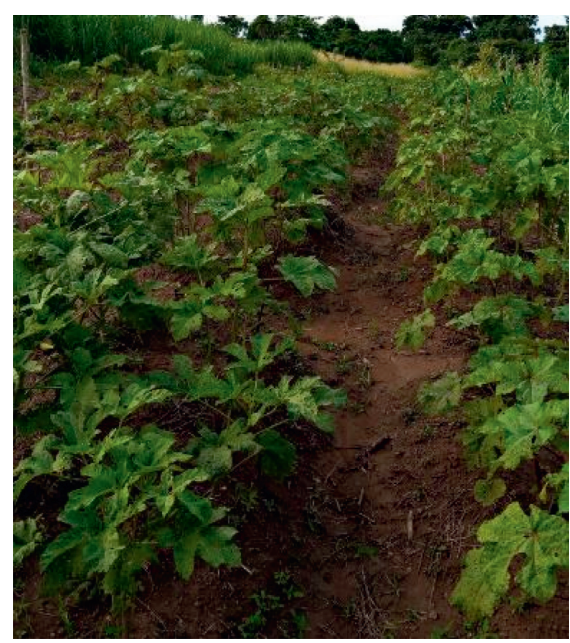

(b)

Figure 2: Vegetative stage of okra on the field.

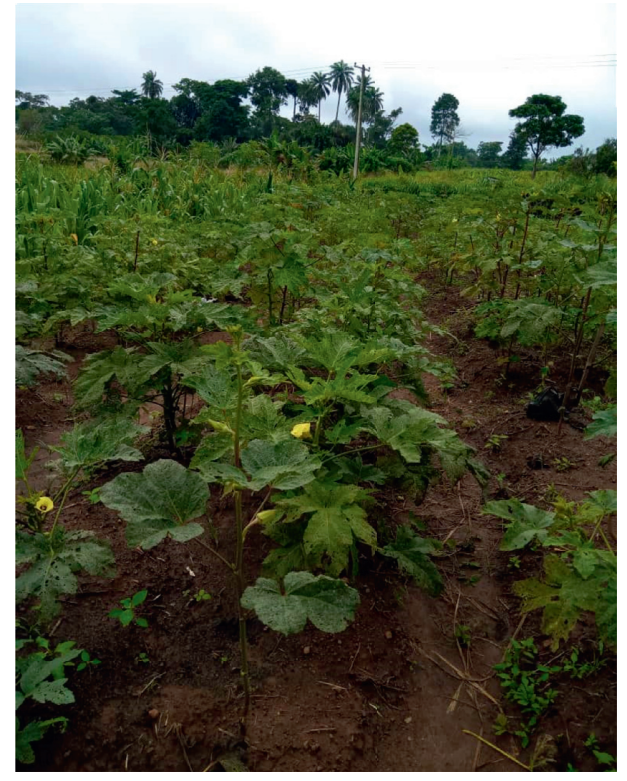

(a)

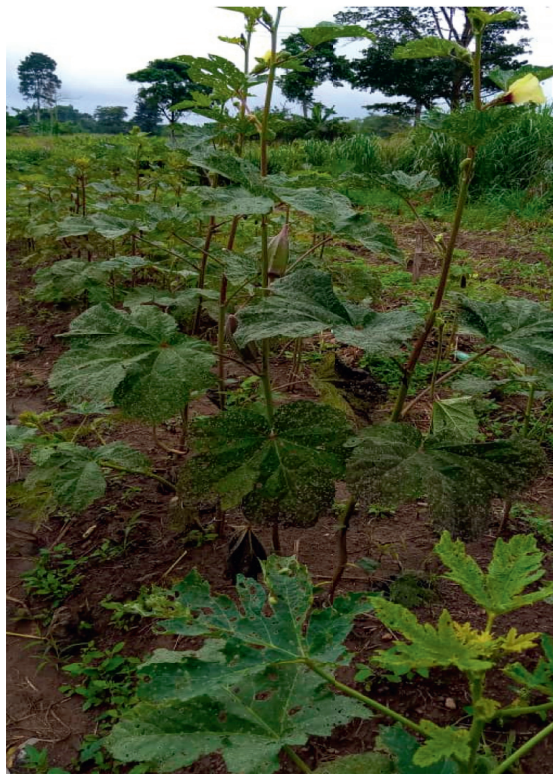

(b)

Figure 3: Okra plant at flowering stage on the field.

NGB00298, NGB00308, and NGB00326 were not significantly different from one another but were significantly different from other genotypes in height. NGB00293, NGB00346, NGB00350, NGB00369A, NGB00360B, NGB00409, and NGB00427 were significantly the same but significantly different from others in height. All the genotypes have different plant heights both at days to $50 \%$ flowering and at marketable fruit maturity, which range from 16.87 (NGB00340) to 110.90 (NGB00308) for days to $50 \%$ flowering and 42.33 (NGB00297B) to 171.80 (NGB00308) for marketable fruit maturity.

NGB00298 recorded the highest number of days to $50 \%$ flowering (135.00) while NGB00430 recorded the lowest number of days to $50 \%$ flowering (48.00). NGB00355,
NGB00356, and NGB00326 are not significantly different in the number of days they flowered, while there were significant differences among the genotypes in the number of days they flowered.

A high range of variability occurs for number of seeds per pod, number of pods per plant, and pod weight for all the forty genotypes studied. Significant variability also occurred in other characters studied such as number of leaves, petiole length, internode length, number of locules, peduncle length, fruit length, and fruit diameter.

3.3. Principal Component Analysis (PCA). The eigenvalues, percentage variance of five principal components (PC) axes, and the eigenvectors of fourteen morphological characters, 


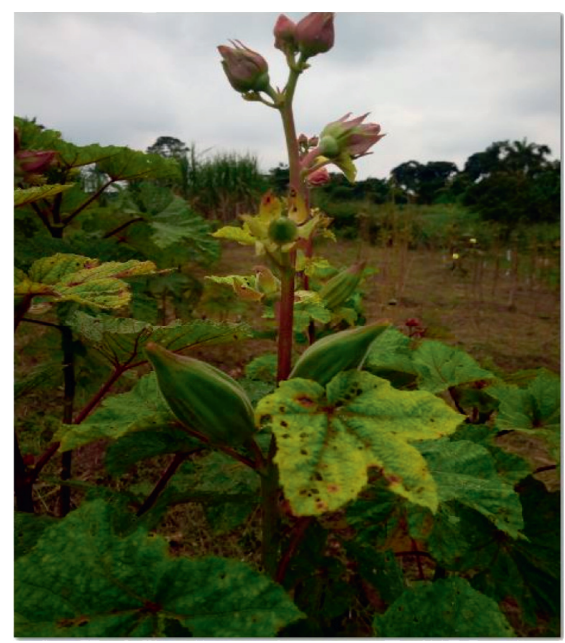

(a)

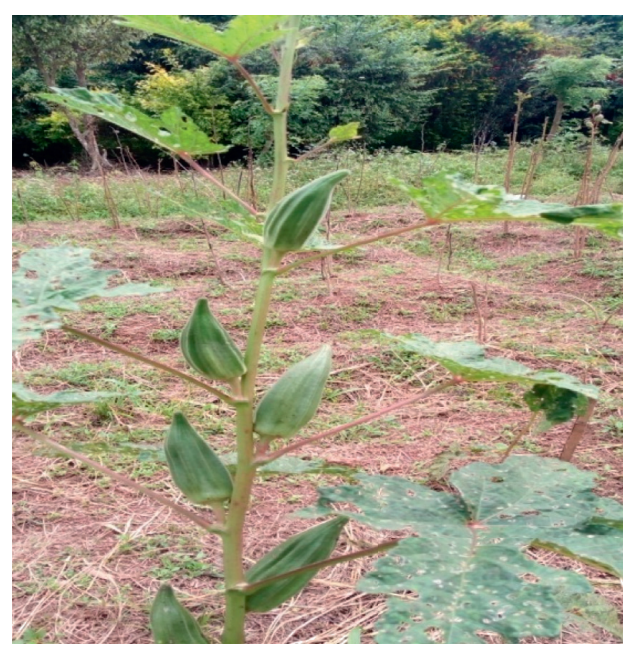

(b)

FIGURE 4: Okra plant at fruiting stage on the field.

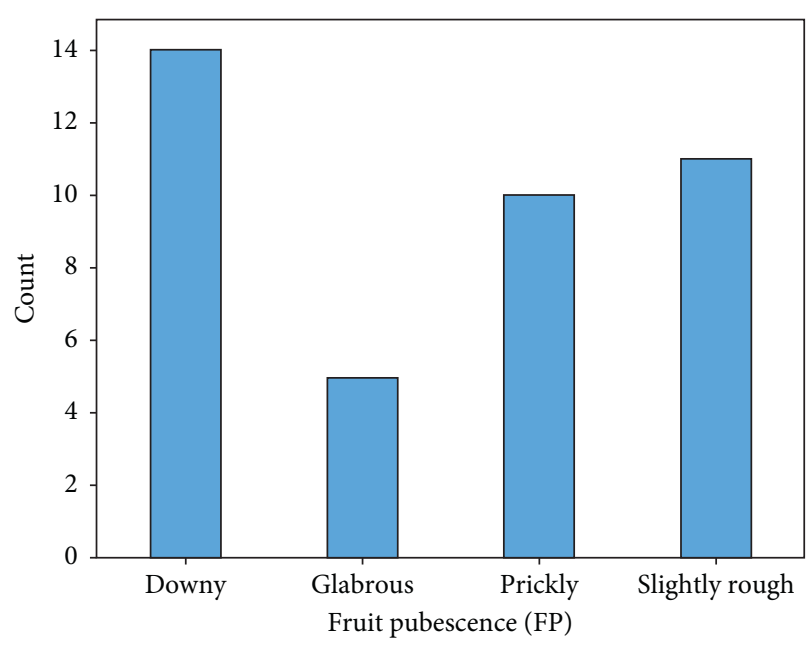

FIGURE 5: Variation in fruit pubescence in forty genotypes of okra.

fibre content, and seven mineral elements of okra are presented in Table 4. The first three PC axes had eigenvalues of $6.28,5.08$, and 2.29 , respectively, and jointly accounted for 62.04 percent of the total variation among the genotypes. The fourth and fifth PC axes explained about 7.31 and 6.96, respectively, of the total variation. However, the five PC axes explained $76.3 \%$ of the total variation among the forty genotypes. The scores of the major characters describing the first five principal axes are presented in Table 5. In this table, quantitative traits, fibre content, and mineral elements with eigenvectors $>0.3$ were significant in their contribution to loading each PC axis. The first principal component axis which accounted for the highest proportion (28.55\%) was mostly loaded by petiole length, number of pods, and pod weight. The second principal axis was loaded by days to $50 \%$ flowering, days to maturity, and mineral element (zinc). The third principal component axis was loaded by fruit length, potassium, phosphorus, and sodium, while the fourth principal component axis was loaded by peduncle length, fruit length, pod weight, calcium, and magnesium, and the fifth principal component axis was dominated by number of locules, fibre, and sodium.

The configuration of the forty genotypes of okra along the first principal component axes is illustrated in Figures $6-8$. The ordination of genotypes on axes 1 and 2 (Figure 6) which accounted for $51.64 \%$ of the total variation showed genotypes NGB00326, NGB00298, and NGB00369A as the distant genotypes while NGB00369B, NGB00302, NGB00371, NGB00486, and NGB00470 were distinct from others. Genotypes NGB00308, NGB00298, and NGB00369A were the most distant genotypes in Figure 8.

3.4. Single-Linkage Cluster Analysis (SLCA). Genetic relationships among the forty genotypes of okra based on fourteen quantitative traits are displayed in the form of a dendrogram (Figure 9), generated using the single-linkage cluster analysis. At $100 \%$ level of similarity, all the genotypes were distinct from one another while at $28 \%$ similarity level, all the genotypes have formed two clusters. Only genotypes NGB00298A, NGB00323, NGB00339, and NGB00345 were most similar to one another and different from others at $86 \%$ level of similarity. At 84\% level of similarity, NGB00465 and NGB00340 had joined the first four genotypes to form clusters. At $43 \%$ level of similarity, five clusters were formed (I, II, III IV, and V). Cluster I comprises NGB00203, cluster II comprises NGB00409, cluster III has twenty-seven genotypes, cluster IV has NGB00308 and NGB00326 genotypes, while cluster V comprises two subclusters. Subcluster I has genotypes NGB00293 and NGB00304. The second subcluster was further divided into various subclusters with seven different genotypes. At $60 \%$ level of similarity, fifteen clusters were formed. Ten clusters were solitary, while five clusters consisted of more than one, up to seven genotypes. Cluster III consisted of seventeen genotypes, cluster XV consisted of seven genotypes, clusters V, IX, and XIV consisted of two genotypes each while clusters I, II, IV, VI, VII, VIII, X, XI, XII, and XIII are made up of one genotype 
TABLE 1: Variation in qualitative traits of forty genotypes of okra.

\begin{tabular}{|c|c|c|c|c|c|c|}
\hline Genotypes & $\mathrm{SP}$ & $\mathrm{FP}$ & SC & $\mathrm{PC}$ & $\mathrm{FC}$ & PFMS \\
\hline NGB00378A & Glabrous & Downy & Green & Yellow & Green & Erect \\
\hline NGB00299 & Conspicuous & Prickly & Green & Yellow & Green & Erect \\
\hline NGB00302 & Conspicuous & Prickly & Green & Yellow & Green & Erect \\
\hline NGB00298 & Slight & Slightly rough & Green & Yellow & Green & Erect \\
\hline NGB00350 & Conspicuous & Prickly & Green & Yellow & Green & Erect \\
\hline NGB00304 & Conspicuous & Prickly & Purple-Green & Yellow & Purple-green & Erect \\
\hline NGB00346 & Conspicuous & Prickly & Green & Yellow & Green & Erect \\
\hline NGB00355 & Conspicuous & Prickly & Red-Green & Yellow & Green & Erect \\
\hline NGB00303 & Glabrous & Downy & Purple-Green & Yellow & Purple-green & Erect \\
\hline NGB00331 & Slight & Slightly rough & Green & Yellow & Purple-green & Erect \\
\hline NGB00356 & Slight & Downy & Green & Yellow & Green & Erect \\
\hline NGB00293 & Glabrous & Glabrous & Red-Green & Yellow & Yellowish-green & Horizontal \\
\hline NGB00347 & Slight & Slightly rough & Purple & Yellow & Purple-green & Erect \\
\hline NGB00297 & Slight & Prickly & Green & Yellow & Green & Pendulous \\
\hline NGB00369 & Conspicuous & Prickly & Green & Yellow & Green & Erect \\
\hline NGB00326 & Glabrous & Glabrous & Green & Yellow & Yellowish-green & Horizontal \\
\hline NGB00371 & Slight & Slightly rough & Red-Green & Yellow & Green & Erect \\
\hline NGB00308 & Glabrous & Glabrous & Green & Yellow & Yellowish-green & Erect \\
\hline NGB00378B & Glabrous & Slightly rough & Green & Yellow & Green & Erect \\
\hline NGB00430 & Glabrous & Slightly rough & Green & Yellow & Green & Erect \\
\hline NGB00296A & Glabrous & Downy & Green & Yellow & Green & Erect \\
\hline NGB00297 & Glabrous & Slightly rough & Green & Yellow & Green & Erect \\
\hline NGB00323 & Glabrous & Downy & Green & Yellow & Green & Erect \\
\hline NGB00332 & Slight & Slightly rough & Purple-Green & Yellow & Purple-green & Erect \\
\hline NGB00335 & Glabrous & Downy & Green & Yellow & Green & Erect \\
\hline NGB00338 & Glabrous & Downy & Green & Yellow & Green & Erect \\
\hline NGB00339 & Conspicuous & Prickly & Purple-Green & Yellow & Purple-green & Erect \\
\hline NGB00351 & Slight & Prickly & Green & Yellow & Green & Erect \\
\hline NGB00369 & Slight & Slightly rough & Green & Yellow & Green & Erect \\
\hline NGB00383 & Glabrous & Downy & Green & Yellow & Green & Erect \\
\hline NGB00386 & Glabrous & Downy & Green & Yellow & Green & Erect \\
\hline NGB00340 & Downy & Downy & Green & Yellow & Green & Erect \\
\hline NGB00427 & Glabrous & Glabrous & Green & Yellow & Yellowish-green & Erect \\
\hline NGB00345 & Slight & Slightly rough & Yellowish-green & Yellow & Yellowish-green & Erect \\
\hline NGB00409 & Slight & Glabrous & Green & Yellow & Green & Erect \\
\hline NGB00465 & Slight & Downy & Green & Yellow & Green & Erect \\
\hline NGB00470 & Downy & Downy & Red-Green & Yellow & Purple-green & Erect \\
\hline NGB00480 & Glabrous & Downy & Green & Yellow & Green & Erect \\
\hline NGB00486 & Slight & Slightly rough & Red-Green & Yellow & Purple-green & Erect \\
\hline NGB00489 & Downy & Downy & Green & Yellow & Green & Erect \\
\hline
\end{tabular}

SP: stem pubescence; FP: fruit pubescence; SC: stem colour; PC: petal colour; FC: fruit colour; PFMS: position of fruit on the main stem.

each. In this study, the maximum genetic similarity index was $85 \%$ recorded between NGB00339 and NGB00345 as the closet pair of accessions.

\section{Discussion}

Highly significant differences for all the characters indicated the presence of a great amount of diversity in all the characters studied. This may be due to differences in the genetic component of the various genotypes. This is in accordance with the findings of Priyanka et al. [18], Sharma et al. [22], Singh et al. [23], Ahiakpa et al. [24], and Aladele et al. [12]. This also corroborates with the findings of Ariyo [13] and Adeniji [25] who stated the role of differences in the genetic makeup of different varieties in the yield determination of okra. The variability can be used to improve the crop for the desired character through selection. No significant differences were observed within replications except for days to maturity, and this shows that there is uniformity in the field which has no effect on the performance of the genotypes for all the characters studied except for days to maturity. This is in agreement with the findings of Priyanka et al. [18], who also had no significant difference within replication for all the twenty-nine genotypes of okra studied.

The very high level of coefficient of variation obtained for pod weight and number of pods is an indication of wide genetic variability among the forty genotypes of okra for these traits, so any improvement of the crop for further breeding work could be directed to these characters.

All the genotypes flowered and matured at different times, and this shows they were genetically different from one another and shows a high prospect for selection for these characters. Genotypes such as NGB00430, NGB00331, 


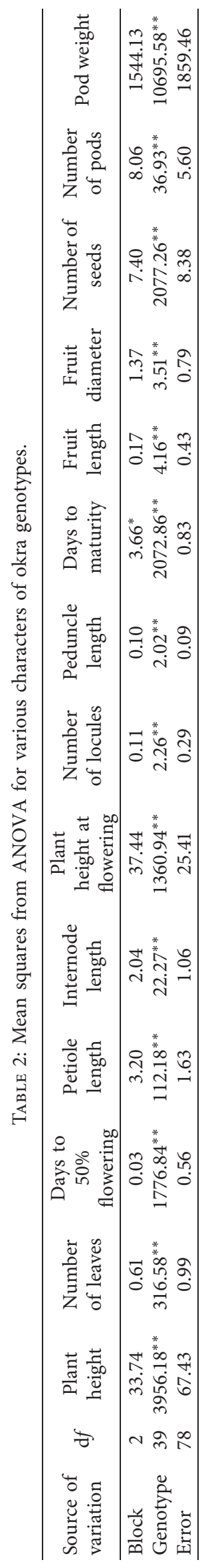




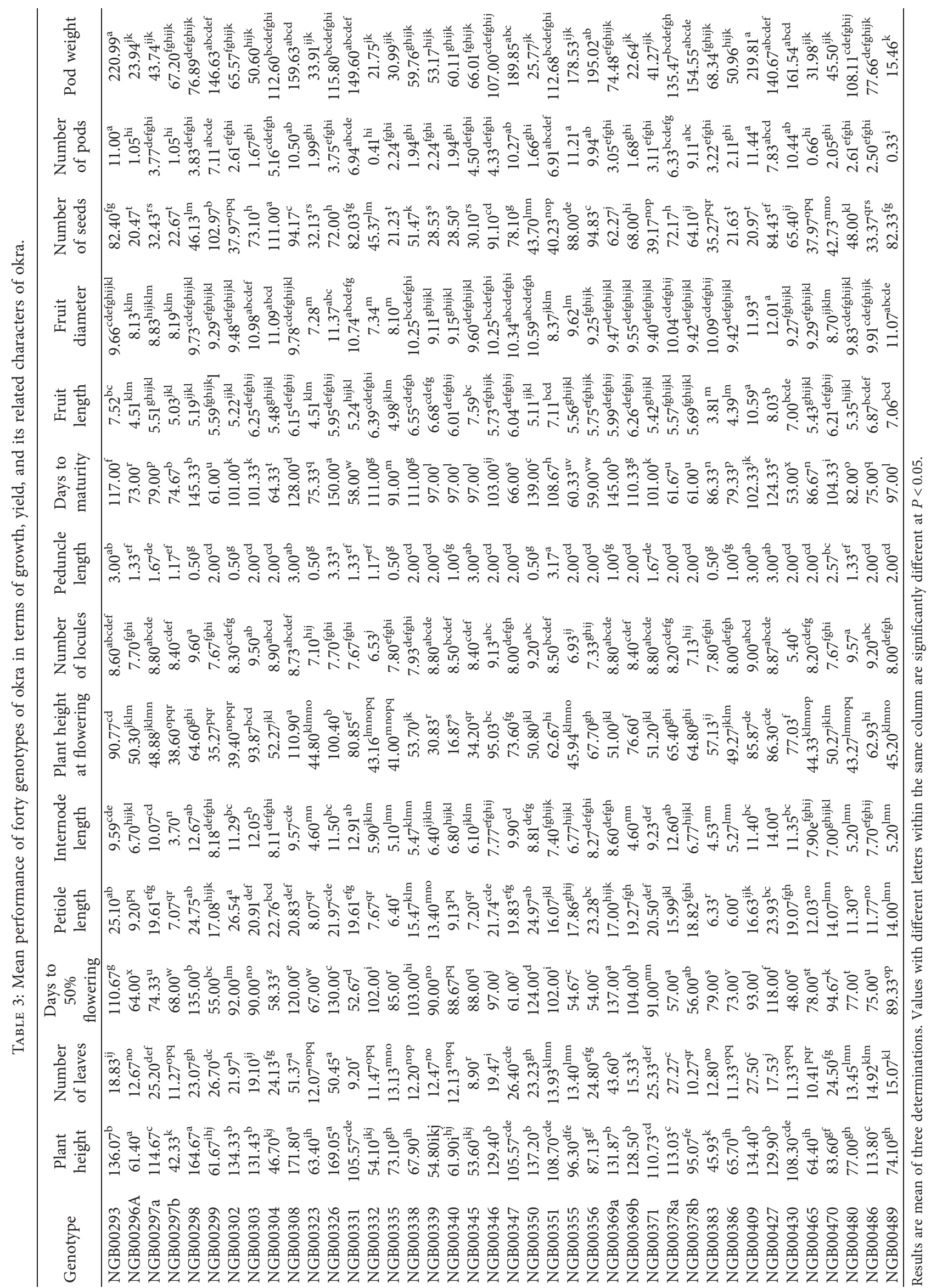


TABLE 4: Eigenvalues, percentage of total variation accounted for, and cumulative percentage by the first six principal component axes of okra.

\begin{tabular}{lccc}
\hline Principal component axes & Eigenvalue & Total variation accounted for (\%) & Cumulative percentage \\
\hline 1 & 6.28 & 28.55 & 28.55 \\
2 & 5.08 & 23.09 & 51.64 \\
3 & 2.29 & 10.39 & 62.04 \\
4 & 1.61 & 7.31 & 69.35 \\
5 & 1.53 & 6.96 & 76.30 \\
\hline
\end{tabular}

TABLE 5: The five principal component axes and their characters.

\begin{tabular}{|c|c|c|c|c|c|}
\hline Character & PCA1 & PCA 2 & PCA3 & PCA4 & PCA5 \\
\hline Plant height & 0.24 & 0.29 & 0.10 & -0.20 & 0.00 \\
\hline Number of leaves & 0.17 & 0.24 & 0.25 & -0.15 & 0.05 \\
\hline Days to flowering & -0.03 & 0.42 & -0.04 & -0.06 & 0.03 \\
\hline Petiole length & 0.30 & 0.14 & 0.05 & -0.21 & -0.21 \\
\hline Internode length & 0.29 & 0.12 & 0.08 & -0.16 & -0.06 \\
\hline Plant height at flowering & 0.28 & 0.17 & 0.04 & -0.05 & 0.01 \\
\hline Number of locules & 0.00 & 0.26 & -0.07 & 0.04 & -0.41 \\
\hline Peduncle length & 0.25 & 0.09 & -0.20 & 0.31 & 0.26 \\
\hline Days to maturity & -0.03 & 0.41 & -0.04 & -0.08 & 0.03 \\
\hline Fruit length & 0.19 & 0.13 & -0.30 & 0.44 & 0.17 \\
\hline Fruit diameter & 0.24 & 0.15 & -0.06 & 0.13 & -0.26 \\
\hline Number of seeds & 0.28 & -0.03 & 0.14 & -0.02 & -0.15 \\
\hline Number of pods & 0.32 & -0.08 & 0.19 & 0.26 & 0.12 \\
\hline Pod weight & 0.31 & -0.06 & 0.17 & 0.31 & 0.02 \\
\hline Fibre & -0.22 & 0.08 & 0.25 & -0.01 & -0.31 \\
\hline Potassium & -0.22 & 0.21 & 0.33 & 0.07 & 0.27 \\
\hline Phosphorus & -0.12 & 0.24 & -0.38 & -0.07 & 0.17 \\
\hline Sodium & 0.01 & 0.04 & 0.43 & -0.20 & 0.49 \\
\hline Calcium & -0.18 & 0.18 & 0.27 & 0.39 & -0.04 \\
\hline Magnesium & -0.21 & 0.16 & 0.25 & 0.41 & -0.14 \\
\hline Iron & -0.17 & 0.24 & -0.01 & 0.09 & -0.21 \\
\hline Zinc & -0.12 & 0.32 & -0.22 & -0.05 & 0.28 \\
\hline
\end{tabular}

Values in bold indicate traits with significant contribution to the total variation.

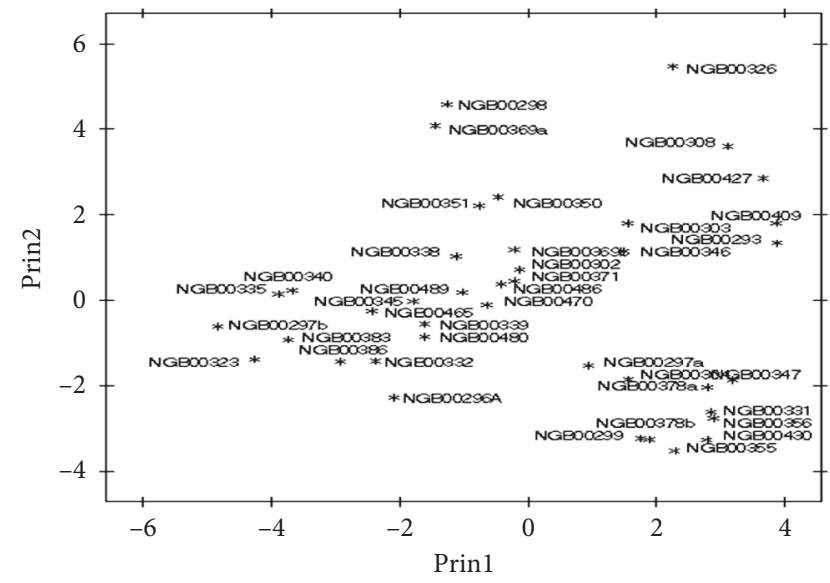

Figure 6: Configuration of the 40 okra genotypes under principal component axes 1 and 2 .

NGB00356, NGB00355, NGB00299, NGB00378b, NGB00378a, and NGB00304 that flowered and matured much more earlier than others could be selected as parents when breeding for early maturity in okra because days to flowering is significant and positively correlated with days to maturity. This corroborates the findings of Ariyo and Odulaja [14].

All the genotypes have different plant heights both at days to $50 \%$ flowering and at marketable fruit maturity, which range from 16.87 (NGB00340) to 110.90 (NGB00308) for days to $50 \%$ flowering and 42.33 (NGB00297b) to 169.05 (NGB00326) for marketable fruit maturity. Plant height at flowering has a lot of implications on plant breeding programme. A very tall and slender stem will cause the lodging rate near harvesting to be increased, thereby reducing the yield of crops as a result of inadequate dry matter production. This is in consonance with reports by Doku [26] and Akinyele and Oseikita [27] who worked on rice and okra, respectively.

High range of variability occurs for number of seeds per pod, number of pods per plant, and pod weight for all the forty genotypes studied. Seed and pod yield could be improved by using genotypes with higher number of seeds per pod, number of pods per plant, and pod weight as parents in the hybridization programme. This is in accordance with the findings of Akinyele and Osekita [27], who stated that an 


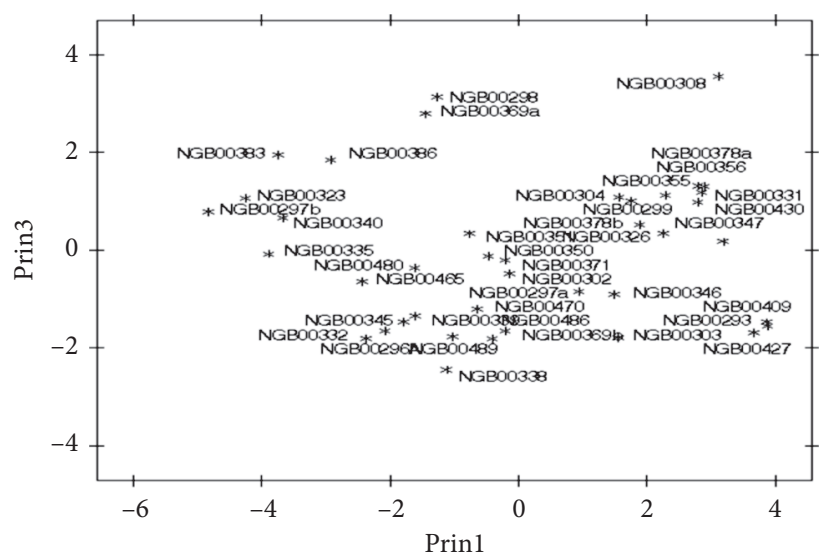

FIGURE 7: Configuration of the 40 okra genotypes under principal components 1 and 3.

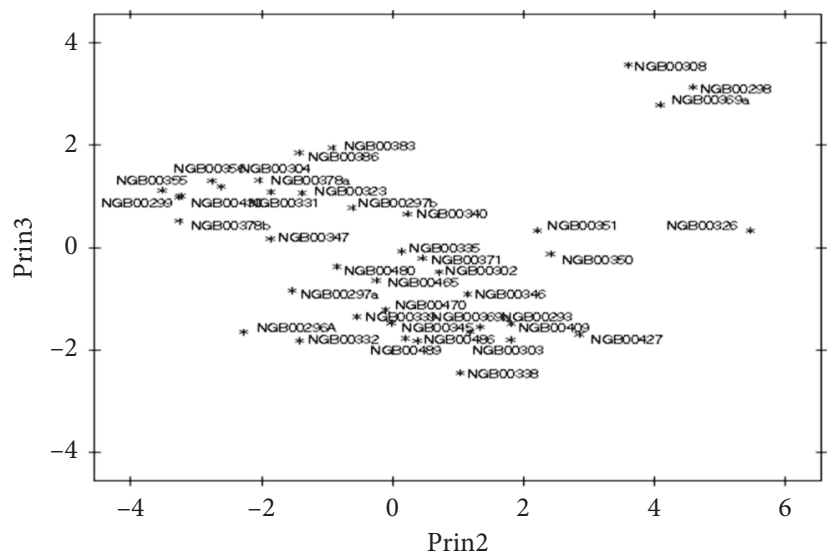

Figure 8: Configuration of the 40 okra genotypes under principal components 2 and 3.

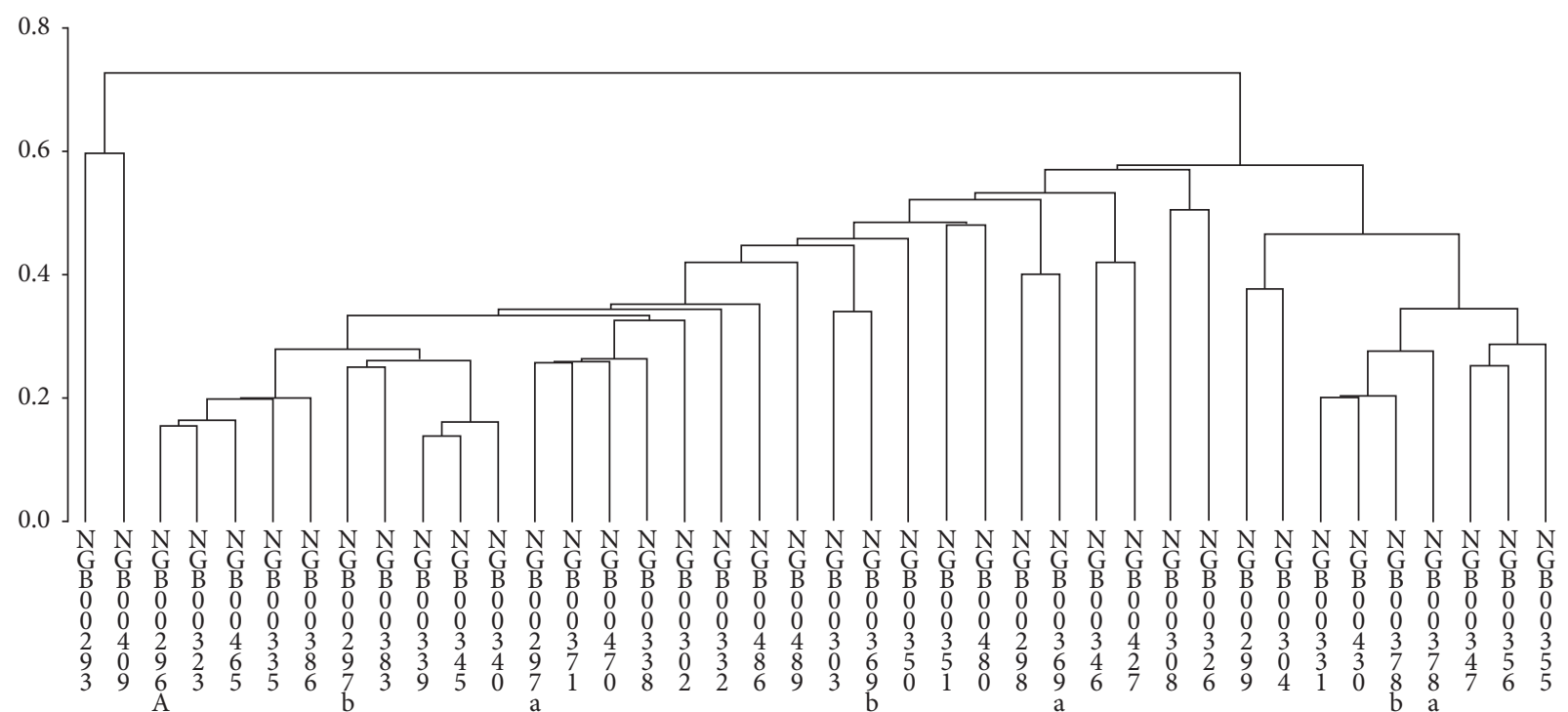

Figure 9: A dendrogram showing the genetic relationship among forty genotypes of okra based on quantitative traits using single-linkage cluster analysis. 
increased number of seeds and per plant could lead to improvement of seed yield.

Significant differences also occurred in other characters studied such as number of leaves, petiole length, internode length, number of locules, peduncle length, fruit length, and fruit diameter, which shows that these characters can form the basis of selection of these genotypes for hybridization experiment depending on the trait of interest to breeders. This is in agreement with the reports of Saran et al. [28], Rajeev et al. [19], Bhagasara et al. [29], Oluwa and Kehinde [30], and Patel et al. [31].

Number of leaves is an important component in determining the performance of any crop. Leaves serve as organs of photosynthesis in the plant, and thus, the greater the number of leaves a plant has, the higher the photosynthetic rate of that plant, which will result in higher production of food particles (glucose) in the plant and consequently higher crop yield. This is in collaboration with the findings of Eshiet and Brisibe [16], who also observed variation in the number of leaves, pod length, and one hundred seed weight of the cultivars of okra they studied.

Results on qualitative traits obtained in this study showed that okra genotypes exhibited different degrees of fruit pubescence ranging from prickly, downy, slightly rough to glabrous with the majority of the fruits being downy. This result corroborates those of Bish et al. [32] and Thomas [33] who found the downy type of fruit pubescence to be the most pronounced, followed by slightly rough, while prickly fruits were the least in the okra accessions they studied.

Petal colour was found to be all yellow in all the genotypes of okra studied. This in agreement with the observation of Myanmar [34] who found petal colour to be $100 \%$ yellow for all 40 okra accessions examined. Akinyele and Akinlosotu [35] also found similar results in their okra research. This is in contrast to the findings of Ahiakpa et al. [24] who reported that petal colour was either cream or yellow with golden yellow flowers (cream) being the highest.

Most of the colour of the fruits was green followed by purple-green colour while yellowish-green were the minority. This is contrary to the report of Ahiakpa et al. [24] who found yellowish-green as the most predominant fruit colour while green and green with red patches were least observed among the accessions.

Diversity was also observed in the position of fruit on the main stem of the crop. Most of the genotypes have their fruits in an erect position on the main stem as against only small number of them that were horizontal and pendulous. This is in accordance with the observation made by Ahiakpa et al. [24] who is working on tomatoes.

The authors in their research $[13,36,37]$ stated that principal component analysis (PCA) is a very important multivariate statistical technique for species classification. The identification by principal component analysis of plant height, number of leaves, days to flowering, petiole length, internode length, plant height at flowering, number of locules, peduncle length, days to maturity, fruit length, fruit diameter, number of seeds, number of pods, pod weight, fibre, potassium, phosphorus, sodium, calcium, magnesium, iron, and zinc as the major components of variation among the genotypes of okra indicated the reliability in the use of these characters in characterizing okra genotypes.

Results of the principal component analysis showed that $76.30 \%$ of the total variability among the okra genotypes evaluated in this study was accounted for the first five principal components. Thus, a greater percentage of the total variation was explained by these components. This is in agreement with the findings of Ogunbayo et al. [38], TorresMoran et al. [39], Amoatey et al. [40] who in their research reported $76.62 \%, 75.77 \%$, and $78.51 \%$, respectively, of the total variability. The total contribution of the five principal component axes $(76.30 \%)$ in this study was higher than reports made by Moukoumbi et al. [41], Nwangburuka et al. [42], and Campos et al. [43], who reported 64.32\%, 66.37\%, and $64.5 \%$, respectively, of the total variability. They are however lower than the total variability observed by Doku [26] and Ahiakpa et al. [24] as $01.87 \%$ and $82.97 \%$, respectively.

Clustering is a multivariate technique that can conveniently show the pattern of genetic relationships or proximity among accessions [44]. Cluster III consisted of seventeen genotypes, cluster XV consisted of seven genotypes, clusters V, IX, and XIV consisted of two genotypes each while clusters I, II, IV, VI, VII, VIII, X, XI, XII, and XIII are made up of one genotype each. This corroborates the findings of earlier researchers $[20,45]$ who reported that major clusters are made up of single cluster, and genotypes in single clusters which are different from others may serve as prospective parents for breeding programme [24, 46], and this shows their distinctiveness and importance due to different exceptional characters possessed by them [20]. The genotypes grouped together in one cluster are less different than those which are placed in a different cluster [47]. According to Andersson et al. [48] who stated that the genetic similarity index (GSI) of two or more accessions should be equal to or greater than $95 \%$ if they are to be taken as genetically identical. In this study, the maximum genetic similarity index was $85 \%$ recorded between NGB00339 and NGB00345 as the closest pair of genotypes.

\section{Conclusion}

The essence of variability studies in crop species is to reveal differences in the genetic makeup and the pattern of it in crop germplasm. The product of this assessment therefore becomes the material for crop improvement. The very high level of coefficient of variation obtained for pod weight and number of pods is an indication of wide genetic variability among the forty genotypes of okra for these traits, so any improvement of the crop for further breeding work could be directed to these characters. All the genotypes flowered and matured at different times, and this shows they were genetically different from one another and shows a high prospect for selection for these characters. A high range of variability occurs for number of seeds per pod, number of pods per plant, and pod weight for all the forty genotypes studied. Results of the principal component analysis showed that $76.30 \%$ of the total variability among the okra genotypes evaluated in this study was accounted for the first five 
principal components. Thus, a greater percentage of the total variation was explained by these components.

\section{Data Availability}

The datasets generated during and/or analysed during the current study are not publicly available due to the problem of plagiarism but are available from the corresponding author upon reasonable request.

\section{Conflicts of Interest}

The authors declare that they have no conflicts of interest.

\section{Authors' Contributions}

RJ collected, analysed, and interpreted data. OJ reviewed and corrected the manuscript. CO designed the study and involved in the write-up.

\section{Acknowledgments}

Dr. A.O., Oduwaye of the Federal University of Agriculture, Abeokuta, Nigeria, assisted in statistical analysis of the work.

\section{References}

[1] C. W. C. Kendall and D. J. A. Jenkins, "A dietary portfolio: maximal reduction of low-density lipoprotein cholesterol with diet," Current Atherosclerosis Reports, vol. 6, no. 6, pp. 492-498, 2004.

[2] J. S. Pandey and C. Kouame, "Vegetables," in Plant Resources of Tropical Africa 2, G. J. H. Grubben and O. A. Denton, Eds., pp. 532-538, PROTA Foundation, Backhuys Publishers, Leiden, Netherlands, 2004.

[3] O. J. Oyelade, B. I. O. Ade-Omowaye, and V. F. Adeomi, "Influence of variety on protein, fat contents and some physical characteristics of okra seeds," Journal of Food Engineering, vol. 57, no. 2, pp. 111-114, 2003.

[4] S. Kumar, S. Dagnoko, A. Haougui, A. Ratnadass, D. Pasternak, and C. Kouame, "Okra (Abelmoschus spp L.) in west and Central africa: potential and progress on its improvement. A special review," African Journal of Agricultural Research, vol. 5, no. 25, pp. 3590-3598, 2010.

[5] R. R. Schippers, African Indigenous Vegetables- An Overview of the Cultivated Species, University of Greenwich, London, UK, 2000.

[6] F. G. Habtamu, R. Negussie, D. H. Gulelat, Z. W. Ashagrie, and B. Fekadu, "Nutritional quality and health benefits of "okra" (Abelmoschus esculentus): a review," International Journal of Nutrition and Food Sciences, vol. 4, no. 2, pp. 208-215, 2015.

[7] E. I. Moyin-Jesu, "Use of plant residues for improving soil fertility, pod nutrients, root growth and pod weight of okra (Abelmoschus esculentum L)," Bioresource Technology, vol. 98, no. 11, pp. 2057-2064, 2007.

[8] National Academies Press, Committee to Review Dietary Reference Intakes for Vitamin D and Calcium, Food and Nutrition Board, Institute of Medicine. Dietary Reference Intakes for Calcium and Vitamin D, National Academies Press, Washington, DC, USA, 2010.

[9] T. K. Kiran and C. Ravisankar, "Genetic variability and multivariate analysis in okra (Abelmoschus esculentus
L. Moench)," Tropical Agricultural Research, vol. 16, pp. 99113, 2004.

[10] O. J. Ariyo, "Measurement and classification of genetic diversity in okra (Abelmoschus esculentus)," Annals of Applied Biology, vol. 116, no. 2, pp. 335-341, 1990.

[11] J. Ren, J. R. McFerson, R. Li, and S. Kresovich, "Identities and relationships among Chinese vegetable brassicas as determined by random amplified polymorphic DNA markers," Journal of the American Society for Horticultural Science, vol. 120, no. 3, pp. 548-555, 1995.

[12] S. E. Aladele, O. J. Ariyo, and L. Robert de, "Genetic relationship among west african okra (Abelmoschus caillei) and asian genotypes (Abelmoschus esculentus) using RAPD," African Journal of Biotechnology, vol. 7, no. 10, pp. 1426-1431, 2008.

[13] O. J. Ariyo, "Genetic diversity in west african okra (Abelmoschus caillei (A.Chev.) stevels). Multivariate analysis of morphological and agronomic characteristics," Genetic Resources and Crop Evolution, vol. 40, pp. 125-132, 1993.

[14] Q. J. Ariyo and A. Odulaja, "Numerical analysis of variation among accessions of okra [Abelmoschus esculentus (L.) moench], malvaceae," Annals of Botany, vol. 67, no. 6, pp. 527-531, 1991.

[15] S. E. Aladele, "Morphological distinctiveness and metroglyph analysis of fifty accessions of West African okra (Abelmoschus caillei) (A. Chev.) Stevels," Journal of Plant Breeding and Crop Science, vol. 1, no. 7, pp. 273-280, 2009.

[16] A. J. Eshiet and E. A. Brisibe, "Morphological characterization and yield traits analysis in some selected varieties of okra (Abelmoschus esculentus L. Moench)," Advances in Crop Science and Technology, vol. 3, no. 5, pp. 197-201, 2015.

[17] O. G. Kyriakopoulou, P. Arens, K. T. B. Pelgrom, I. Karapanos, P. Bebeli, and H. C. Passam, "Genetic and morphological diversity of okra (Abelmoschus esculentus[L.] Moench.) genotypes and their possible relationships, with particular reference to Greek landraces," Scientia Horticulturae, vol. 171, pp. 58-70, 2014.

[18] V. M. Priyanka, T. Reddy, H. Begum, N. Sunil, and M. Jayaprada1, "Studies on genetic variability, heritability and genetic advance in genotypes of okra [Abelmoschus esculentus (L.) moench]," International Journal of Current Microbiology and Applied Sciences, vol. 7, pp. 401-411, 2018.

[19] K. Rajeev, Yadav, M. M. Syamal, and M. Kumar, "Evaluation of genetic variation, heritability and genetic advance for various traits in okra [abelmoschus esculentus (L.) Moench] under north gangetic plains of Uttar Pradesh," International Journal of Agriculture, Environment and Biotechnology Citation: IJAEB, vol. 9, no. 2, pp. 175-180, 2016.

[20] M. T. Reddy, K. Haribabu, and M. Ganesh, "Genetic variability analysis for the selection of elite genotypes based on pod yield and quality from the germplasm of okra (Abelmoschus esculentus L. Moench)," Journal of Agriculture, Science and Technology, vol. 8, pp. 639-655, 2012.

[21] K. W. Gomez and A. A. Gomez, "Statistical Procedures for Agricultural Research," John Wiley and Sons, London, UK, 2nd edition, 1983.

[22] P. K. Sharma, D. P. Mishra, and D. P. Mishra, "Genetic variability studies for yield and its contributing traits in okra [Abelmoschus esculentus (L.) Moench]," Journal of Applied and Natural Science, vol. 8, no. 3, pp. 1634-1637, 2016.

[23] S. Singh, M. Rathore, D. Goyary et al., "Induced ectopic expression of At-CBF1 in marker-free transgenic tomatoes confers enhanced chilling tolerance," Plant Cell Reports, vol. 30, no. 6, pp. 1019-1028, 2011. 
[24] J. K. Ahiakpa, P. D. Kaledzi, E. B. Adi, S. Peprah, and H. K. Dapaah, "Genetic diversity, correlation and path analyses of Okra (Abelmoschus spp. (L.) Moench) germplasm collected in Ghana," International Journal of Development and Sustainability, vol. 2, no. 2, pp. 1396-1415, 2013.

[25] O. T. Adeniji, "Inheritance studies in West African Okra (A. caillei)," M. Agric. thesis, University of Agriculture, Abeokuta, Nigeria, 2003.

[26] A. H. Doku, "Characterisation of 18 African rice (Oryza glaberrima) in Ghana,", M.Phil. thesis, Department of Nuclear Agriculture and Radiation Processing, University of Ghana, pp. 87-102, Department of Nuclear Agriculture and Radiation Processing, University of Ghana, 2011.

[27] B. O. Akinyele and O. S. Oseikita, "Correlation and path coefficient analyses of seed yield attributes in okra (Abelmoschus esculentus (L.) Moench)," African Journal of Biotechnology, vol. 14, pp. 1330-1336, 2006.

[28] P. L. Saran, A. K. Godara, G. Lal, and I. S. Yadav, "Correlation and path coefficient analysis in ber genotypes for yield and yield contributing traits," Indian Journal of Horticulture, vol. 64, no. 4, pp. 459-460, 2007.

[29] V. K. Bhagasara, B. R. Ranwah, B. L. Meena, and R. Khan, "Estimation of GCV, PCV, heritability and genetic gain for yield and its related components in sorghum [Sorghum bicolor (L.) moench]," International Journal of Current Microbiology and Applied Sciences, vol. 6, no. 5, pp. 1015-1024, 2017.

[30] O. O. Oluwa and O. B. Kehinde, "Genetic variability studies in West African okra (Abelmoschus caillei)," Agriculture and Biology Journal of North America, vol. 2, no. 10, pp. 13261335, 2011.

[31] R. Patel, S. K. Sengupta, and A. K. Verma, "Studies on genetic parameter in okra (Abelmoschus esculentus (L.) Monech)," Trends in Biosciences, vol. 7, no. 14, pp. 1808-1811, 2014.

[32] I. S. Bish, R. K. Mahajan, and R. S. Rana, "Genetic diversity in South Asian okra (Abelmoschus esculentus) germplasm collection," Annals of Applied Biology, vol. 126, pp. 539-550, 1995.

[33] T. A. Thomas, Catalogue of Okra (Abelmoschus esculentus (L.) Moench) Germplasm, Part II, NBPGR, New Delhi, India, 1991.

[34] A. K. Myanmar, "Evaluation of okra germplasm," ARCAVRDC Training Report, pp. 55-76, Kasetsart University, Bangkok, Thailand, 1995.

[35] I. O. Akinyele and A. Akinlosotu, "Effect of germination on the oligosaccharide and nutrient content of cowpea," Journal of Food Chemistry, vol. 39, pp. 157-165, 1991.

[36] J. B. Morris, "Sword bean (Canavalia ensiformis (L.) DC.) genetic resources regenerated for potential medical, nutraceutical and agricultural traits," Genetic Resources and Crop Evolution, vol. 54, no. 3, pp. 585-592, 2007.

[37] V. Vadivel and K. Janardhnan, "Nutritional and antinutritional characteristics of seven south Indian wild legumes," Plant Foods for Human Nutrition, vol. 60, pp. 1-7, 2005.

[38] S. A. Ogunbayo, D. K. Ojo, R. Guei, O. O. Oyelakin, and K. A. Sanni, "Phylogenetic diversity and relationships among 40 rice accessions using morphological and RAPDs techniques," African Journal of Biotechnology, vol. 4, no. 11, pp. 1234-1244, 2005.

[39] M. I. Torres-Morán, M. Escoto-Delgadillo, J. Ron-Parra et al., "Relationships among twelve genotypes of roselle (Hibiscus sabdariffa L.) cultivated in western Mexico," Industrial Crops and Products, vol. 34, no. 1, pp. 1079-1083, 2011.

[40] H. Amoatey, G. Klu, E. Quartey et al., "Genetic diversity studies in 29 accessions of okra (Abelmoschus spp L.) using 13 quantitative traits," American Journal of Experimental Agriculture, vol. 5, no. 3, pp. 217-225, 2015.

[41] Y. D. Moukoumbi, M. Sie, R. Voudouhe et al., "Assessing phenotypic diversity of interspecific rice varieties using agromorphological characterisation," Journal of Plant Breeding and Crop Science, vol. 3, no. 5, pp. 74-86, 2011.

[42] C. C. Nwangburuka, O. B. Kehinde, D. K. Ojo, O. A. Denton, and A. R. Popoola, "Morphological classification of genetic diversity in cultivated okra, Abelmoschus esculentus (L) Moench using principal component analysis (PCA) and single linkage cluster analysis (SLCA)," African Journal of Biotechnology, vol. 10, no. 54, pp. 11165-11172, 2011.

[43] E. T. Campos, M. A. G. Espinosa, M. L. Warburton, and A. V. Monter, "Characterisation of madrin (Citrus spp) using morphological and AFLP markers," Interciencia, vol. 30, no. 11, pp. 1-14, 2005.

[44] A. A. Afifi and V. Clark, Computer Aided Multivariate Analysis, Van Nostrand Reinhold, NewYork, NY, USA, 1990.

[45] K. Pradip, D. K. De Akotkar, and A. K. Pal, "Genetic variability and diversity in okra [Abelmoschus esculentus (L).Moench]," Electronic Journal of Plant Breeding, vol. 1, no. 4, pp. 393-398, 2010.

[46] S. K. Torkpo, E. Y. Danquah, S. K. Offei, and E. T. Blay, "Esterase, total protein and seed storage protein diversity in okra (Abelmoschus esculentus L. Moench)," West African Journal of Applied Ecology (WAJAE), vol. 9, pp. 855-4307, 2006.

[47] D. Muluken, M. Wassu, and G. Endale, "Genetic diversity of Ethiopian okra collections through multivariate analysis at werer, rift valley of Ethiopia," The International Journal Of Science \& Technoledge, vol. 3, no. 8, pp. 186-193, 2015.

[48] M. S. Andersson, R. Schultze-Kraft, M. Peters, M. C. Duque, and G. Gallego, "Extent and structure of genetic diversity in a collection of the tropical multipurpose shrub legume Cratylia argentea (Desv.) O. Kuntze as revealed by RAPD markers," Electronic Journal of Biotechnology, vol. 10, no. 3, pp. 1-9, 2007. 